\title{
Variation between sheep in renal excretion of $\left[{ }^{14} \mathrm{C}\right]$ allantoin
}

\author{
P. Prasitkusol ${ }^{1 *}$, E. R. Ørskov ${ }^{2} \dagger$, X. B. Chen ${ }^{3}$, F. D. DeB. Hovell ${ }^{4}$ and D. J. Kyle ${ }^{1}$ \\ ${ }^{1}$ Rowett Research Institute, Bucksburn, Aberdeen AB21 9SB, Scotland, UK \\ ${ }^{2}$ International Feed Resources Unit, Macaulay Land Use Research Institute, Craigiebuckler, Aberdeen AB15 8QH, \\ Scotland, UK \\ ${ }^{3}$ Lucta (Guangzhou) Flavours Co. Ltd., 173-175 Youyi Road, Guangzhou Economic \& Technological Development District, \\ Guangzhou 510730, People's Republic of China \\ ${ }^{4}$ Department of Agriculture and Forestry, University of Aberdeen, 581 King Street, Aberdeen AB24 5UA, Scotland, UK
}

(Received 2 July 2001 - Revised 3 January 2002 - Accepted 30 January 2002)

\begin{abstract}
The objectives of the present study were to investigate the recovery of $\left[{ }^{14} \mathrm{C}\right]$ allantoin in urine of sheep dosed intravenously and degradation of allantoin by rumen micro-organisms. The recovery of $\left[{ }^{14} \mathrm{C}\right]$ allantoin in the urine of eight sheep was measured during three periods in two experiments. Individual values of $\left[{ }^{14} \mathrm{C}\right]$ allantoin recovery varied from 66 to $95 \%$ (mean value 83 (SE 1.6) \%). The recovery of $\left[{ }^{14} \mathrm{C}\right]$ allantoin showed no relation to the level of feed intake. There was some evidence that glomerular filtration rate was an important factor affecting the amount of urinary allantoin recovered in one experiment. Incomplete recovery of plasma $\left[{ }^{14} \mathrm{C}\right]$ allantoin in the urine indicated losses of plasma $\left[{ }^{14} \mathrm{C}\right]$ allantoin via non-renal routes. This is supported by the disappearance of ${ }^{14} \mathrm{C}$ from rumen contents incubated in vitro with $\left[{ }^{14} \mathrm{C}\right]$ allantoin for $48 \mathrm{~h}(88 \%)$ and the presence of ${ }^{14} \mathrm{C}$ in saliva in vivo from sheep sampled after dosing with $\left[{ }^{14} \mathrm{C}\right]$ allantoin. However, the amount of ${ }^{14} \mathrm{C}$ activity in the saliva was very low (equivalent to only $1.5 \%$ of the total dose in sheep producing saliva at a rate of 15 litres/d). The proportion of renal and non-renal excretion of purine derivatives was found to be unpredictable both between and within individual animals. The factors responsible for this variability need to be identified, and existing models of excretion of purine derivatives may need to be modified accordingly to improve their accuracy of prediction. A single intravenous injection of $\left[4,5-{ }^{14} \mathrm{C}\right]$ allantoin provides a simple alternative to infusion methods used to measure the proportion of plasma allantoin excreted in the urine of sheep. Using this method it may be feasible to validate PD excretion models in other ruminant livestock.
\end{abstract}

Renal excretion: Purine derivatives: Allantoin: Radioactivity: Sheep

The proportion of plasma purine derivatives (PD) excreted in urine is an important variable required in establishing a mathematical model to estimate microbial protein supply in the small intestine. The recovery of plasma PD in the urine of sheep and cattle varies by approximately 77$84 \%$ between species and between breeds within species (Chen et al. 1990b, 1997; Verbic et al. 1990; Balcells et al. 1991; Surra et al. 1997). There is, however, no obvious metabolic or physiological reason indicating why recovery should be at this level. Recently, Kahn \& Nolan (2000) showed that $94 \%\left[{ }^{14} \mathrm{C}\right]$ allantoin was recovered in the urine of sheep after a single intravenous injection of $\left[{ }^{14} \mathrm{C}\right]$ allantoin. Liang et al. (1999) reported that the recovery of radioactive tracer was lower than that of European cattle when Kedah-Kelantan cattle (Bos indicus) and water buffalo (Bubalus bubalis) were dosed intravenously with $\left[{ }^{14} \mathrm{C}\right]$ uric acid. However, the recovery of total PD of Kedah-Kelantan cattle was shown to be similar to that of European cattle by Pimpa et al. (2001) using duodenal infusion with purine bases. In contrast, differences in recovery of $\left[{ }^{14} \mathrm{C}\right]$ allantoin in urine were found between Ongole cattle (Bos indicus) and Bali cattle (Bos banteng) by Prasitkusol (2001). The present prediction models were established with European breeds of sheep and cattle (for sheep Chen et al. 1990b; Balcells et al. 1991; for cattle Verbic et al. 1990). These models may not be suitable for other ruminant animal species such as Zebu cattle (Bos indicus) and buffalo (Bubalis bubalis). For example,

\footnotetext{
Abbreviations: GFR, glomerular filtration rate; PD, purine derivative.

* Present address: Department of Agriculture, Rajabhat Institute Kanchanaburi, Kanchanaburi 71000, Thailand.

† Corresponding author: Professor E. R. Ørskov, fax +44 1224311 556, email b.orskov@mluri.sari.ac.uk
} 
Ayala \& Hovell (1997) calculated a negative value of estimated microbial $\mathrm{N}$ when using the model proposed by Verbic et al. (1990) in Zebu cattle. In addition, different populations (e.g. animals in different geographical regions) within European breeds of sheep and cattle may also differ in the recovery of plasma PD in urine. In order to improve the accuracy of estimation of rumen microbial protein outflow using the PD method, the variable representing the proportion of plasma PD excreted in urine in mathematical models of sheep and cattle PD excretion may need to be modified.

Previously, the intragastric infusion technique (Ørskov et al. 1979) and replacement of digesta by a synthetic digesta containing known amounts of purines (Balcells et al. 1991) have been used to measure the recovery of exogenous PD in the urine. This approach would be strengthened if alternative methods were available for measurement of PD recovery. Allantoin is the catabolic end product of purine metabolism and the majority of PD excretion (i.e. hypoxanthine, xanthine and uric acid) in the urine of ruminants animal. Allantoin has been shown to be the only PD that increased in response to incremental inputs of duodenal purines (Chen et al. 1990b; Balcells et al. 1991). In the present study $\left[4,5-{ }^{14} \mathrm{C}\right]$ allantoin was used to measure the proportion of plasma allantoin excreted in the urine of sheep. The effect of level of feed intake and glomerular filtration rate (GFR) on recovery of $\left[{ }^{14} \mathrm{C}\right]$ allantoin in urine were also examined.

Complete recovery of plasma PD in sheep urine has not been reported in any published work to date (Chen et al. 1990 b 1997; Balcells et al. 1991; Surra et al. 1997; Kahn \& Nolan, 2000). Losses of plasma PD via recycling into the rumen and subsequent degradation in the gastrointestinal tract have been reported by Chen et al. (1990a) and Kahn \& Nolan (2000). In the present study, possible nonrenal routes of plasma PD disposal were investigated by the measurement of PD degradation by rumen microorganisms in vitro.

\section{Experimental methods}

Two in vivo experiments (Expts 1 and 2) and one in vitro experiment (Expt 3) were conducted. In Expt 1, the effect of feed intake level on the proportion of plasma PD excreted in urine was measured using $\left[{ }^{14} \mathrm{C}\right]$ allantoin. In Expt 2 animals were all given the same feed intake, to determine the extent of variation in the recovery of urinary plasma PD between animals. In both experiments the GFR of sheep was estimated. In Expt 3 the same incubation medium as that used in the gas production technique of Menke \& Steingass (1988) was used to determine the degradability of $\left[{ }^{14} \mathrm{C}\right]$ allantoin by rumen micro-organisms.

\section{Animals and management}

Four rumen-cannulated (i.d. $41 \mathrm{~mm}$ ) female sheep, crossbred between Suffolk $\times$ Greyface and Greyface $\times$ Finn Dorset, approximately 1 year of age and $49-53 \mathrm{~kg}$ were used in Expt 1 (sheep A, B, C and D). Four female sheep of the same breed and age, $42-50 \mathrm{~kg}$ were used in Expt 2 (sheep E, F, G and H). All animals were fitted with jugular catheters $($ single lumen, i.d. $0.08 \times$ outer diameter $1.20 \mathrm{~mm}$, Polyvinyl chloride tube; Silverwater B.C., NSW, Australia) $24 \mathrm{~h}$ before making a single injection of tracer into a jugular vein.

\section{Treatments and design}

Expt 1. The experimental design was a $4 \times 3$ incomplete Latin square. Three levels of feed intake $(800,1200$ and $1600 \mathrm{~g} / \mathrm{d}$ of the diet as fed; $920 \mathrm{~g} \mathrm{DM} / \mathrm{kg}(\mathrm{g} / \mathrm{kg}$; hay 50 , barley 30 , molasses 10 , fish meal $9 \cdot 1$, salt $0 \cdot 6$, minerals and vitamins $0.1 \%$ )) were allocated to the four sheep for three experimental periods. The periods lasted for $16 \mathrm{~d}$ with $9 \mathrm{~d}$ adaptation and $7 \mathrm{~d}$ measurement. A single injection of $\left[{ }^{14} \mathrm{C}\right]$ allantoin was introduced into a jugular vein on day 10 of the experiment. The sheep were kept in metabolism crates with unrestricted access to clean drinking water and given the diet as two equal meals at 08.00 and 16.00 hours. The animals were maintained in this condition throughout the experimental period.

Expt 2. All animals were fed $1 \mathrm{~kg} / \mathrm{d}$ (as fed) of the same diet used in Expt 1. The experiment comprised three experimental periods each of $13 \mathrm{~d}$ duration with $6 \mathrm{~d}$ adaptation and $7 \mathrm{~d}$ measurement. On day 6 each sheep was given a single intravenous dose of $\left[{ }^{14} \mathrm{C}\right]$ allantoin. The animals were maintained as in Expt 1.

Expt 3. $\left[4,5-{ }^{14} \mathrm{C}\right]$ Allantoin was incubated with sheep rumen contents at $39^{\circ} \mathrm{C}$ in conical flasks for $48 \mathrm{~h}$ to study the disappearance of $\left[{ }^{14} \mathrm{C}\right]$ allantoin. The conical flask was sealed with a rubber bung fitted with a glass tube and silicone tubing which was opened periodically to vent excess $\mathrm{CO}_{2}$. A sample of the incubation mixture $(60 \mathrm{ml})$ (containing one vol. rumen contents, collected from the sheep maintained on a hay and grass cube diet, and two vol. artificial saliva) and $400 \mathrm{mg}$ ground hay were added to a $100 \mathrm{ml}$ conical flask. Then 0 (control), 1 or $2 \mathrm{ml}$ of $\left[{ }^{14} \mathrm{C}\right]$ allantoin solution was added. All measurements were made in duplicate.

Tracer solution. $\left[4,5-{ }^{14} \mathrm{C}\right]$ Allantoin (Amersham International, Amersham, Bucks, UK), purity 0.96 and specific activity $222 \mathrm{MBq} / \mathrm{mmol}$, was used as a tracer. The tracer solution for each experiment was prepared by dissolving $4 \mathrm{mg}$ cold allantoin (allantoin carrier) and $5.55 \mathrm{MBq}$ of labelled allantoin in $200 \mathrm{ml}$ medical saline. The solution was sonicated to ensure that all particles were dissolved completely, then it was sterilized at $121^{\circ} \mathrm{C}, 103 \mathrm{kPa}$ before administration. The average dose introduced to each sheep in both Expts 1 and 2 was 1.11 (SD 0.08) MBq. A $50 \mathrm{ml}$ plastic disposable sterile syringe (catheter tip; Sherwood Medical, Crawley, Sussex, UK) was used to administer the tracer solution to the animal. Approximately $40 \mathrm{ml}$ tracer solution was injected via the catheter during a period of 1-2 min. After each injection, the catheter was flushed thoroughly with heparinized saline to ensure that no labelled solution remained in the catheter. The dose of $\left[{ }^{14} \mathrm{C}\right]$ allantoin given was determined by weighing the syringe before and after injection.

\section{Sample collection}

In Expt 1 saliva and rumen contents were collected at 2, 4, 6, 8 
and $24 \mathrm{~h}$ after the single tracer injection and centrifuged at $26000 \mathrm{~g}$ for $10 \mathrm{~min}$ to separate feed particles and measured the radioactivity of ${ }^{14} \mathrm{C}$. Total faeces were collected daily and $10 \%$ samples were stored at $4{ }^{\circ} \mathrm{C}$ in polythene bags. All faeces samples from an individual animal during each period were pooled, mixed, subsampled and stored at $-20^{\circ} \mathrm{C}$ until analysis. In Expts 1 and 2, all urine was collected for $7 \mathrm{~d}$ after the tracer injection to ensure complete collection of radioactivity in the urine. On the first day the urine was collected twice at 6 and $24 \mathrm{~h}$ after dosing. The urine was collected into $\mathrm{H}_{2} \mathrm{SO}_{4}(100 \mathrm{ml} / \mathrm{l})$ to maintain the final urine $\mathrm{pH}$ below 3 then made up to $3 \mathrm{~kg}$ with clean water, subsampled and stored at $-20^{\circ} \mathrm{C}$ for further analysis. Blood samples $(10 \mathrm{ml})$ were withdrawn daily before and after injection of labelled allantoin from a jugular vein into a heparinized vacutaner and then centrifuged at $575 \mathrm{~g}$ for $20 \mathrm{~min}$. The plasma was stored at $-20^{\circ} \mathrm{C}$. The radioactivity of $\left[{ }^{14} \mathrm{C}\right]$ allantoin solution injected into the animals used in Expts 1 and 2 was measured over a range of 10 to $100 \mu \mathrm{l}$ tracer solution to produce a calibration curve, so that the amount of activity injected to an animal was known. In Expt 3, $2 \mathrm{ml}$ incubated liquor (rumen contents in artificial saliva) from the flask were collected prior to incubation $(0 \mathrm{~h})$ and after incubation at 1, 2, 3, 5, 7, 9, 24, 30 and $48 \mathrm{~h}$. When taking a sample, the conical flask was flushed with $\mathrm{CO}_{2}$ to maintain anaerobic conditions. The total activity present in the sample collected prior to incubation (at $0 \mathrm{~h}$ ) was the total dose. Each sample collected after incubation was acidified to remove dissolved $\mathrm{CO}_{2}$. For acidification, $0.5 \mathrm{ml}$ sample was pipetted into a $20 \mathrm{ml}$ liquid scintillation vial, and $0.2 \mathrm{ml} 2 \mathrm{M}-\mathrm{HCl}$ were added. $\mathrm{HCl}$ was used in preference to $\mathrm{H}_{2} \mathrm{SO}_{4}$ for acidification of the samples for compatibility with the scintillation fluid. The acidified sample was mixed, left in a fume cupboard for approximately $12 \mathrm{~h}$ then prepared for the measurement of radioactivity.

\section{Analytical methods}

Measurements of radioactivity in samples of urine, saliva, rumen fluid or tracer solution $\left(\left[4,5-{ }^{14} \mathrm{C}\right]\right.$ allantoin) were made using a Tri-Carb ${ }^{\circledR}$, Model 1900 TR Liquid Scintillation Analyser (Packard ${ }^{\circledR}, \mathrm{CT}$, USA). Samples consisting of $0.5 \mathrm{ml}$ urine, $1 \mathrm{ml}$ saliva or $2 \mathrm{ml}$ rumen contents were thoroughly mixed with 4,4 and $12 \mathrm{ml}$ respectively liquid scintillant (ULTIMA GOLD ${ }^{\mathrm{TM}}$, Packard Instrument Company, CT, USA). In Expt 3, acidified samples $(0.5 \mathrm{ml}$ rumen contents mixed with $0.2 \mathrm{ml} \mathrm{HCl}$ ) were mixed with $14 \mathrm{ml}$ liquid scintillant. The calibration curve was produced by adding different volumes, in the range $10-100 \mu$ l, of the same tracer solution that was injected into the animals to $4 \mathrm{ml}$ liquid scintillant. All samples were counted for a period of $10 \mathrm{~min}$.

DM and organic matter in feed and faeces were measured by drying samples in a hot air oven at $100^{\circ} \mathrm{C}$ for $48 \mathrm{~h}$ (Association of Official Analytical Chemists, 1980). Organic matter and ash content were determined by 'ashing' a sample for $12 \mathrm{~h}$ in a muffle furnace at $550^{\circ} \mathrm{C}$ (Association of Official Analytical Chemists, 1980). Measurement of apparent whole-tract digestibility of DM or organic matter was calculated from the total collection of faeces. Measurement of urinary PD (xanthine, hypoxanthine, uric acid and allantoin were determined using a Technicon Automatic Analyser, and allantoin was measured by HPLC as described by Chen et al. (1990c, 1993).

Recovery of $\left[{ }^{14} \mathrm{C}\right]$ allantoin in urine was calculated from the dose of $\left[{ }^{14} \mathrm{C}\right]$ allantoin injected intravenously and the ${ }^{14} \mathrm{C}$ radioactivity excreted in the urine. Although allantoin is the end product of purine metabolism in sheep and urine collected after dosing was preserved below $\mathrm{pH} 3$, it was critical to ensure that measurement of ${ }^{14} \mathrm{C}$ activity recovered in the urine came exclusively from $\left[4,5-{ }^{14} \mathrm{C}\right]$ allantoin. Precipitation of $\left[{ }^{14} \mathrm{C}\right]$ allantoin in urine using mercuric acetate was used to validate the ${ }^{14} \mathrm{C}$-measurement technique. The test procedure was adapted from that of Stefano et al. (1992) and of Terzuoli et al. (1995). Samples were taken from the same urine sample used to measure the recovery of $\left[{ }^{14} \mathrm{C}\right]$ allantoin. Urine collected during the first $2 \mathrm{~d}(6,24$ and $48 \mathrm{~h}$ ) after injection of $\left[{ }^{14} \mathrm{C}\right]$ allantoin in Expt 1 was used because more than $70 \%$ dosed $\left[{ }^{14} \mathrm{C}\right]$ allantoin was excreted in the first $2 \mathrm{~d}$. The urine was diluted 8 -fold with distilled water, to give an estimated allantoin concentration of $50-100 \mathrm{mg} / \mathrm{l}$. For each sample, $30 \mu \mathrm{l} 2 \mathrm{M}-\mathrm{NaOH}$ and $0.3 \mathrm{ml}$ mercuric acetate solution $(1 \mathrm{~g}$ mercuric acetate and $10 \mathrm{~g}$ sodium acetate in $100 \mathrm{ml}$ water) was added to $0.9 \mathrm{ml}$ diluted urine. The mixture was incubated at $4^{\circ} \mathrm{C}$ for $12 \mathrm{~h}$ then centrifuged at $26000 \mathrm{~g}$ for $20 \mathrm{~min} ; 0.5 \mathrm{ml}$ supernatant fraction was mixed with $4 \mathrm{ml}$ scintillation fluid and radioactivity was measured. Net precipitation was measured as the proportion of total radioactivity that disappeared from the sample after precipitation.

GFR, (litres/d) was determined by measuring the concentrations of creatinine in urine and plasma using a KONE Analyser (KONE Instruments Corporation, Ruukintie Finland). The method of measuring creatinine used on the KONE was based on that of Folin \& Wu (1919, cited by Hawk et al. 1965) and modified from Hawk et al. (1965). GFR was estimated from the measurements of endogenous creatinine in plasma and urine as described by Emslie-Smith et al. (1988). Disappearance of $\left[{ }^{14} \mathrm{C}\right]$ allantoin incubated in rumen contents in vitro was calculated by difference between the radioactivity present in rumen contents taken prior to incubation and that in samples taken at different times during the incubation.

\section{Statistical methods}

ANOVA was conducted using Genstat 5, release 3.2 (1995; Lawes Agricultural Trust, Rothamsted Experimental Station, Rothamsted, Herts., UK). Data from Expt 1 were analysed by ANOVA for an incomplete Latin square design with appropriate error strata to determine the effect of feeding level on $\left[{ }^{14} \mathrm{C}\right]$ allantoin recovery, GFR and PD excretion within animals over the treatment periods and to assess any differences between animals. In Expt 2, ANOVA was used to investigate the differences between animals. Differences between animals on recovery of $\left[{ }^{14} \mathrm{C}\right]$ allantoin in the urine were analysed by ANOVA in which blocks represent experimental periods. The effect of GFR on recovery of $\left[{ }^{14} \mathrm{C}\right]$ allantoin in the urine in Expts 1 and 2 were examined by regression analysis. 
Table 1. Recovery of activity in urine as precipitated $\left[{ }^{14} \mathrm{C}\right]$ allantoin for three time periods*

(Mean values and standard deviations for three experimental periods per sheep)

\begin{tabular}{|c|c|c|c|c|c|c|}
\hline \multirow{3}{*}{$\begin{array}{l}\text { Time period... } \\
\text { Sheep }\end{array}$} & \multicolumn{6}{|c|}{ Recovery (\%) } \\
\hline & \multicolumn{2}{|c|}{$0-6 \mathrm{~h}$} & \multicolumn{2}{|c|}{$6-24 \mathrm{~h}$} & \multicolumn{2}{|c|}{$24-48 h$} \\
\hline & Mean & SD & Mean & SD & Mean & SD \\
\hline A & 97 & 1.2 & 95 & $3 \cdot 6$ & 94 & $6 \cdot 2$ \\
\hline B & 98 & 0.6 & 96 & 0.6 & 93 & $3 \cdot 1$ \\
\hline C & 97 & 0 & 93 & 4.6 & 93 & $9 \cdot 0$ \\
\hline D & 95 & 3.6 & 92 & 2.5 & 90 & 6.7 \\
\hline
\end{tabular}

${ }^{*}$ For details of diets and procedures, see p. 562.

\section{Results}

Expt 1. $\left[{ }^{14} \mathrm{C}\right]$ Allantoin in the urine was almost completely precipitated, although the precipitation of $\left[{ }^{14} \mathrm{C}\right]$ allantoin in some samples was $<90 \%$. (Table 1). Low precipitate activities were not associated with particular animals or particular periods. For example, the precipitation of $\left[{ }^{14} \mathrm{C}\right]$ allantoin from sheep at the same collection time but in different sampling periods indicates the within animal variation as illustrated by sheep A, where precipitation of allantoin from urine sampled at $24-48 \mathrm{~h}$ in periods 1, 2 and 3 were 87, 99 and $96 \%$ respectively. In addition the first urine collection $(0-6 h)$ of three sheep (A, B and C) from three periods showed high precipitation of $\left[{ }^{14} \mathrm{C}\right]$ allantoin $(97-98 \%)$ with slightly lower precipitation $(95 \%)$ in sheep D. High precipitation indicates that any ${ }^{14} \mathrm{C}$ activity present in the urine was mainly in the form of $\left[{ }^{14} \mathrm{C}\right]$ allantoin. Therefore, the proportion of $\left[{ }^{14} \mathrm{C}\right]$ allantoin in plasma that is excreted into the urine is mainly in the form of $\left[{ }^{14} \mathrm{C}\right]$ allantoin.

$\left[{ }^{14} \mathrm{C}\right]$ Allantoin appeared in the urine soon after the intravenous dose. More than $70 \%$ of the dose was excreted in the first $2 \mathrm{~d}$, and activity fell to background levels within $5 \mathrm{~d}$. However, urine was collected for $7 \mathrm{~d}$ to ensure recovery of all $\left[{ }^{14} \mathrm{C}\right]$ allantoin excreted. The cumulative recovery of $\left[{ }^{14} \mathrm{C}\right]$ allantoin over three periods is shown in Fig. 1.

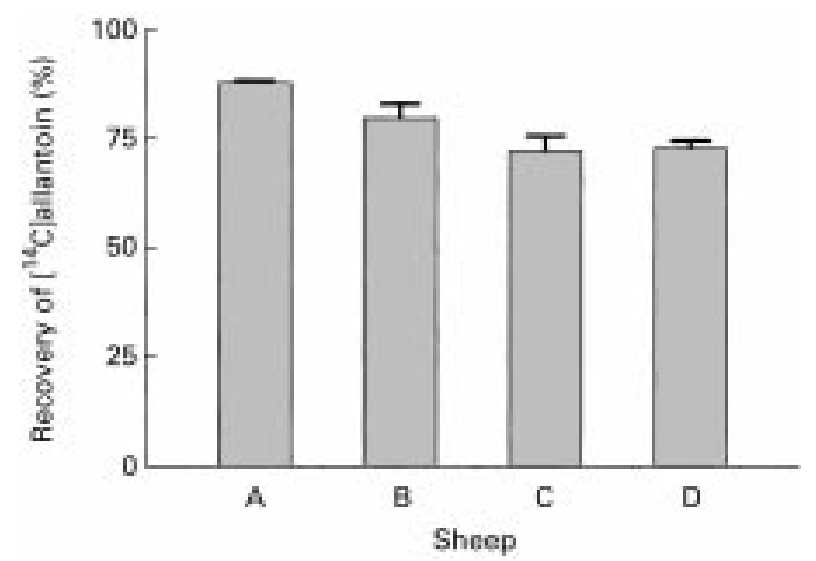

Fig. 1. Recovery of $\left[{ }^{14} \mathrm{C}\right]$ allantoin in the urine of four sheep for three experimental periods per sheep (Expt 1). For details of diets and procedures, see p. 562. Values are means with standard errors shown by vertical bars.
Table 2. Recovery of $\left[{ }^{14} \mathrm{C}\right]$ allantoin in the urine of four sheep given an intravenous dose of $\left[{ }^{14} \mathrm{C}\right]$ allantoin at three levels of feed intake (Expt 1)*

(Mean values for four sheep for three experimental periods per sheep)

\begin{tabular}{lc}
\hline & Recovery $(\%)$ \\
\hline Level of feeding $(\mathrm{g} / \mathrm{d}, n$ 4) & \\
800 & 78.6 \\
1200 & 77.1 \\
1600 & 79.3 \\
SE & 2.49 \\
F test & $P=0.84$ \\
Sheep $(n$ 3) & \\
A & $88.0^{\mathrm{a}}$ \\
B & $79.9^{\mathrm{ab}}$ \\
C & $72.4^{\mathrm{b}}$ \\
D & $73.0^{\mathrm{b}}$ \\
SE & 2.87 \\
F test & $P=0.05$ \\
\hline
\end{tabular}

${ }^{a, b}$ Mean values with unlike superscript letters were significantly different $(P<0.05)$.

${ }^{*}$ For details of diets and procedures, see p. 562.

More than $50 \%\left[{ }^{14} \mathrm{C}\right]$ allantoin recovered was in the urine sampled $6 \mathrm{~h}$ after dosing. The pattern of daily recovery was similar in all three periods. However, the rate and the amount of $\left[{ }^{14} \mathrm{C}\right]$ allantoin recovered were different due to the variation between animals. Sheep A had the highest cumulative recovery in all three periods, while sheep D had high variation between periods. Sheep B had higher cumulative recovery than sheep $\mathrm{C}$ in all three periods.

The proportion of plasma $\left[{ }^{14} \mathrm{C}\right]$ allantoin excreted in the urine from each animal in the three periods is shown in Table 2. $\left[{ }^{14} \mathrm{C}\right]$ Allantoin recovered was different between animals but was not affected by level of feed intake. The average recovery from sheep A, B, C and D in three periods was $88.0,79.9,72.4$ and $73.0 \%$ respectively. The $\left[{ }^{14} \mathrm{C}\right]$ allantoin recovery of sheep A was significantly different from sheep $\mathrm{C}$ and $\mathrm{D}$ but not sheep B. There were no differences in sheep B, C and D.

Digestibility of DM or organic matter of the feed was not significantly affected by the level of intake although there was a tendency for digestibility to decline as intake increased. Digestible DM intake, digestible organic matter intake and PD excretion were increased significantly $(P=0.001)$ as the level of feed intake increased. The average daily PD excretions at the three levels of intake, 800, 1200 and $1600 \mathrm{~g} / \mathrm{d}$, were $0.588,0.884$ and 1.134 (SE 0.05) $\mathrm{mmol} / \mathrm{kg}$ body weight ${ }^{0.75}$ respectively. PD excretion $/ \mathrm{kg}$ digestible organic matter intake did not differ between the three levels of feed intake, the average being $23 \cdot 10$ (SE 1.21$) \quad \mathrm{mmol} / \mathrm{kg}$ digestible organic matter intake. When examined by regression analysis, urinary excretion of PD was positively related to digestible DM intake and digestible organic matter intake (Fig. 2). The daily PD excretion $\left(y \mathrm{mmol} / \mathrm{kg}\right.$ body weight ${ }^{0.75}$ ) increased with level of digestible organic matter intake $(x \mathrm{~g} / \mathrm{kg}$ body weight $\left.^{0.75}\right)\left(y=0.032\left(\right.\right.$ SE 0.005) $x-0.317\left(\right.$ SE 0.2), $R^{2}$ $0.78)$ and digestible DM intake $\left(x \mathrm{~g} / \mathrm{kg}\right.$ body weight $\left.{ }^{0.75}\right)$

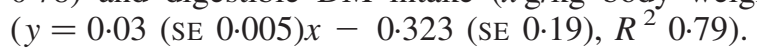



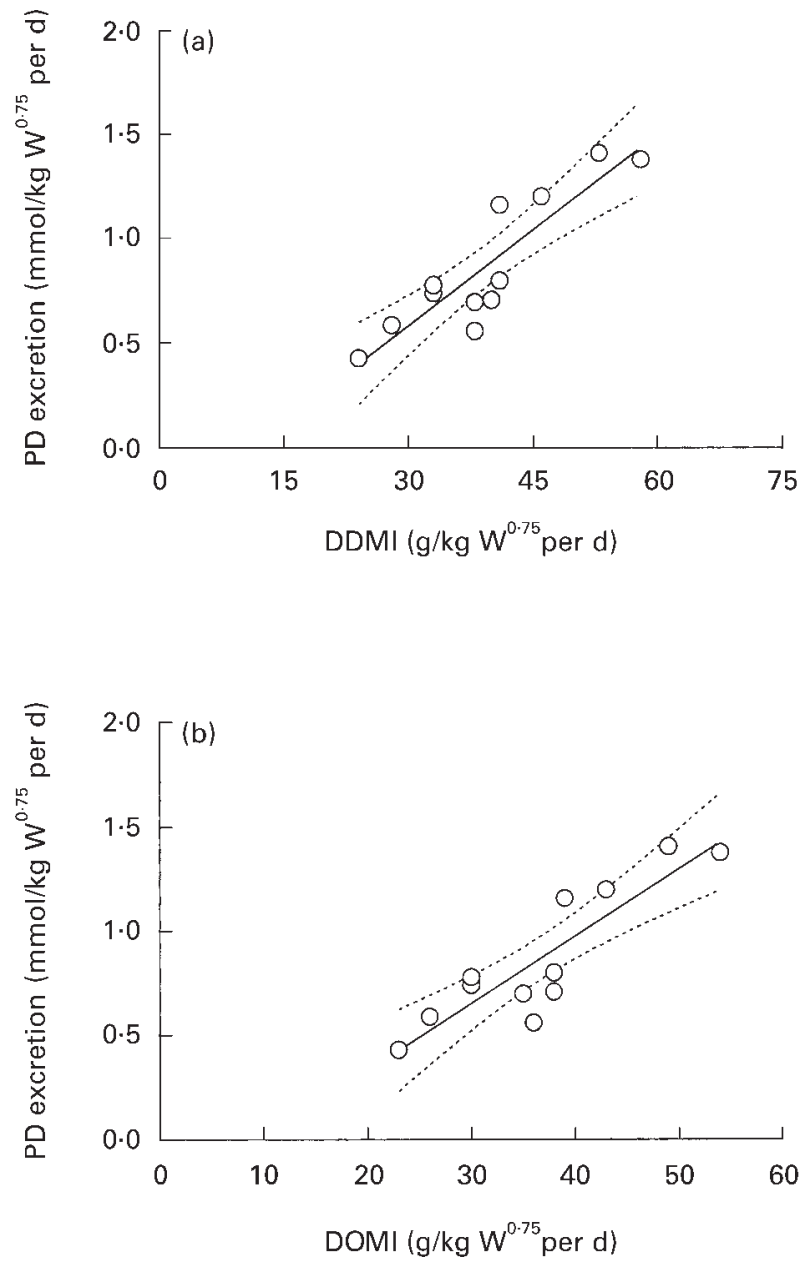

Fig. 2. Linear relationship between urinary excretion of purine derivatives (PD) and (a) digestible DM intake (DDMl; $y=0.03$ (SE $0.005) x-0.32$ (SE 0.19) $R^{2} 0.79, P=0.0001$ ) and (b) digestible organic matter intake (DOMl; $y=0.03$ (SE 0.005) $x-0.32$ (SE 0.2), $R^{2} 0.78, P=0.0001$ ) for four sheep for three experimental periods per sheep (Expt 1). W, body weight. (-), Linear regression; ..., + or $-2 \mathrm{SD}$. For details of diets and procedures, see p. 562.

Table 3 shows the daily excretion of creatinine and the GFR at three levels of feed intake in the four animals. GFR and creatinine excretion showed a tendency to increase with feed intake although differences between the mean values at the three levels of intake were not statistically significant. Linear regression was used to examine the relationship between creatinine excretion and food intake with GFR which showed no significant $(P=0.63)$ effect of level of feed intake on GFR.

However, the GFR for the four animals differed significantly and $\left[{ }^{14} \mathrm{C}\right]$ allantoin recovered in the urine related significantly to GFR. Fig. 3 shows that variation in GFR may account for part of the differences between animals in the recovery of injected $\left[{ }^{14} \mathrm{C}\right]$ allantoin. Animals with a higher GFR showed a tendency to have higher recovery of $\left[{ }^{14} \mathrm{C}\right]$ allantoin in their urine. The correlation coefficient $(r)$ between $\left[{ }^{14} \mathrm{C}\right]$ allantoin recovered in the urine and GFR (litres/kg body weight ${ }^{0.75}$ per d) was 0.76 $(P<0.05)$. It is interesting to note that within each animal, however, GFR was not correlated to the recovery.
Table 3. Proportion of the injected $\left[{ }^{14} \mathrm{C}\right]$ allantoin excreted in urine, daily creatinine excretion and glomerular filtration rate (GFR) of four sheep given three levels of feed intake (Expt 1$)^{*}$

(Mean values for four sheep for three experiments periods per sheep)

\begin{tabular}{cccc}
\hline & $\begin{array}{c}\text { Recovery } \\
(\%)\end{array}$ & $\begin{array}{c}\text { Creatinine excretion } \\
\left(\mathrm{mmol} / \mathrm{kg} \mathrm{W}^{0.75}\right)\end{array}$ & $\begin{array}{c}\text { GFR } \\
\left(\text { litres } / \mathrm{kg} \mathrm{W}^{0.75}\right)\end{array}$ \\
\hline Feed intake $(\mathrm{g} / \mathrm{d})$ & & \\
800 & 78.6 & 436 & 4.88 \\
1200 & 77.1 & 488 & 5.45 \\
1600 & 79.3 & 495 & 6.05 \\
SE & 2.49 & 24.56 & 0.32 \\
Sheep & & & \\
A & $88.0^{\mathrm{a}}$ & $580^{\mathrm{a}}$ & $6.96^{\mathrm{a}}$ \\
B & $79.9^{\mathrm{ab}}$ & $448^{\mathrm{b}}$ & $5.57^{\mathrm{ab}}$ \\
C & $72.4^{\mathrm{b}}$ & $437^{\mathrm{b}}$ & $5.00^{\mathrm{b}}$ \\
D & $73.0^{\mathrm{b}}$ & $427^{\mathrm{b}}$ & $4.32^{\mathrm{b}}$ \\
SE & 2.87 & 28.35 & 0.37 \\
F test & $P=0.05$ & $P=0.05$ & $P=0.03$ \\
\hline
\end{tabular}

W, body weight.

${ }^{a, b}$ Mean values within a column with unlike superscript letters were significantly different $(P<0.05)$.

${ }^{*}$ For details of diets and procedures, see p. 562.

Saliva of sheep collected at different times after a single intravenous injection of $\left[{ }^{14} \mathrm{C}\right]$ allantoin contained ${ }^{14} \mathrm{C}$ although the amount of radioactivity was very low compared to the dose. Approximately $1.5 \%$ of the injected dose would have been secreted into the saliva assuming a sheep produces 15 litres saliva/d (Kay, 1960). No radioactivity was detected in the rumen contents in vivo.

Expt 2. There was no evidence of a relationship between urinary $\left[{ }^{14} \mathrm{C}\right]$ allantoin excretion and GFR (Fig. 4). There was some evidence of a relation when the excretion of this metabolite was examined between periods (Table 4). However, sheep $\mathrm{G}$ and $\mathrm{H}$, which had higher GFR, showed higher rates of excretion of the metabolite than sheep $\mathrm{E}$ and $\mathrm{F}$. The average recovery was $86.8 \%$

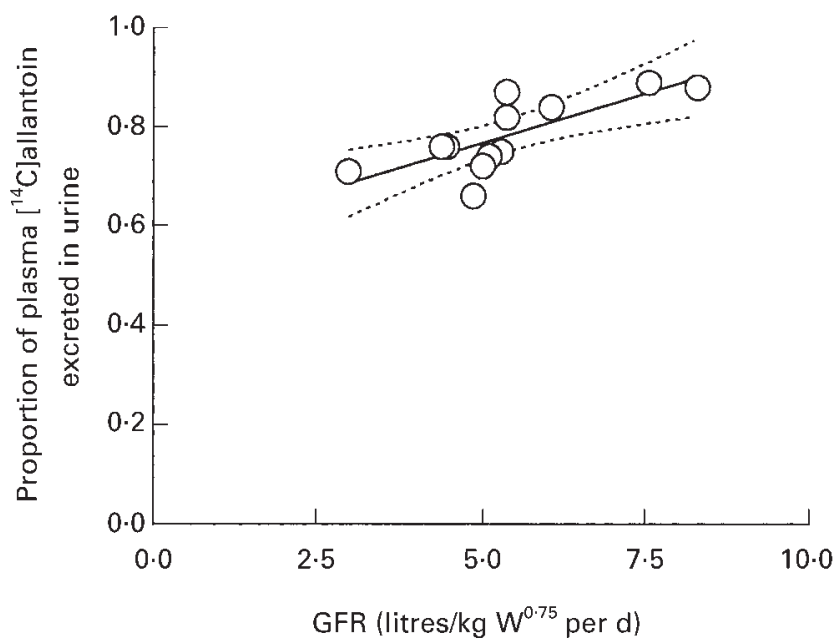

Fig. 3. Linear relationship between recovery of $\left[{ }^{14} \mathrm{C}\right]$ allantoin in urine and glomerular filtration rate (GFR) in four sheep for three experimental periods each $(800,1200$ and $1600 \mathrm{~g} \mathrm{mixed} \mathrm{diet/d;} y=$ 0.05 (SE 0.01)x + 0.54 (SE 0.07); $\left.R^{2} 0.57, P=0.005\right)$ (Expt 1). W, body weight. - , Linear regression; $\cdots,+$ or $-2 \mathrm{SD}$. For details of diets and procedures see p. 562 . 


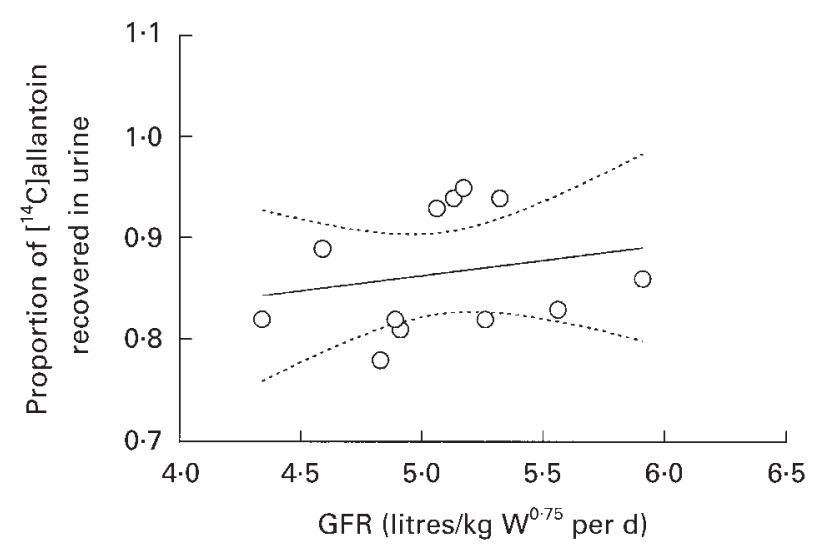

Fig. 4. Relationship between recovery of $\left[{ }^{14} \mathrm{C}\right]$ allantoin in urine and glomerular filtration rate in four sheep fed $1000 \mathrm{~g}$ mixed diet/d for three experimental periods each $(y=0.03$ (SE 0.04) $x+0.7$ (SE 0.23 ), $R^{2} 0.04, P=0.51$ ) (Expt 2). W, body weight. - Linear regression; $\cdots,+$ or -2 SD. For details of diets and procedures, see p. 562.

and ranged from 78.4 to 94.8 . In sheep $\mathrm{F}$, recoveries ranged from 78.4 to $93.2 \%$ over all three periods.

Expt 3. After incubation in rumen contents, $\left[{ }^{14} \mathrm{C}\right]$ allantoin was rapidly degraded (Fig. 5). The disappearance of ${ }^{14} \mathrm{C}$ activity from the liquid was not affected by the volume of tracer solution and was on average $88 \%$ at $48 \mathrm{~h}$. Although the sample was acidified to remove $\mathrm{CO}_{2}$, it is possible that some ${ }^{14} \mathrm{C}$ remained in other products of microbial metabolism of allantoin, for example, ${ }^{14} \mathrm{C}$ incorporation into microbial cells. It is possible that the disappearance of ${ }^{14} \mathrm{C}$ activity was underestimated because of this.

\section{Discussion}

\section{Renal excretion of $\left[{ }^{14}\right.$ C]allantoin in sheep}

Variation of $\left[{ }^{14} \mathrm{C}\right]$ allantoin recovery appeared to be affected by both disposal of plasma $\left[{ }^{14} \mathrm{C}\right]$ allantoin via renal and non-renal routes. Schäli \& Roch-Ramel (1980)

Table 4. Glomerular filtration rate (GFR) and recovery of injected $\left[{ }^{14} \mathrm{C}\right]$ allantoin in the urine from measurement of four sheep given three levels of feed intake (Expt 2)*

(Mean values for four sheep for three experimental periods)

\begin{tabular}{lcc}
\hline & GFR (litres/d) & Recovery (\%) \\
\hline Sheep & & \\
E & 79.06 & 84.07 \\
F & 82.54 & 84.98 \\
G & 103.68 & 88.13 \\
H & 93.46 & 90.13 \\
SEM & 2.7 & 3.6 \\
$P$ value between sheep & 0.004 & 0.33 \\
Period & & \\
1 & 88.62 & 83.20 \\
2 & 89.12 & 84.49 \\
3 & 91.25 & 92.79 \\
SEM & 6.0 & 2.2 \\
$P$ value between periods & 0.75 & 0.03 \\
\hline
\end{tabular}

${ }^{*}$ For details of diets and procedures, see p. 562.

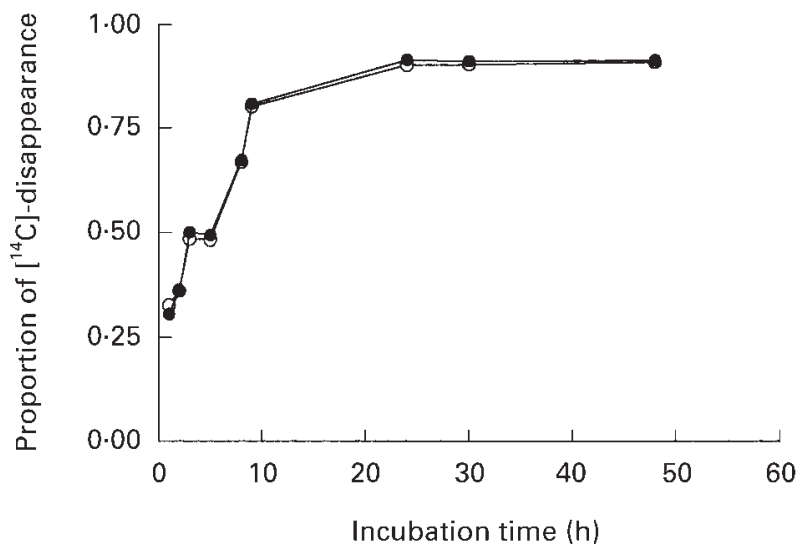

Fig. 5. Disappearance of ${ }^{14} \mathrm{C}$ from rumen contents after incubation of $\left[{ }^{14} \mathrm{C}\right]$ allantoin from $1-48 \mathrm{~h}$ (proportion to total dosing). (- $1 \mathrm{ml}$; (-○—) $2 \mathrm{ml}$. For details of procedures, see p. 562 .

found both net reabsorption and secretion of allantoin in renal tubules of rabbits depending on urine flow rate. However the importance of renal exchange of allantoin in sheep has not been established. The very low amount of ${ }^{14} \mathrm{C}$ activity found in saliva of sheep after a single intravenous injection of $\left[{ }^{14} \mathrm{C}\right]$ allantoin is similar to that reported by Surra et al. (1997) and Kahn \& Nolan (2000). However, these results contrast with those reported by Chen et al. (1990a). In the present study, ${ }^{14} \mathrm{C}$ activity was not detected in the rumen contents of sheep after dosing with $\left[{ }^{14} \mathrm{C}\right]$ allantoin. This may be due to dilution of the activity by a large volume of rumen contents, or rapid breakdown of allantoin by rumen micro-organisms. This explanation is supported by the disappearance of ${ }^{14} \mathrm{C}$ from allantoin caused by rumen micro-organisms in vitro. These results agree with Coleman (1968) and Thornsberry \& Wiseman (1960, cited by Vogels \& Van Drift, 1976) that rumen microbes utilize purine derivatives available in the rumen as sources of $\mathrm{C}$ and $\mathrm{N}$ for growth. Therefore, as suggested by Kahn \& Nolan (2000), allantoin may pass through the blood cell barrier, and be degraded by micro-organisms in the gastrointestinal tract.

\section{The proportion of plasma $\left[{ }^{14}\right.$ C]allantoin excreted in urine}

Use of $\left[{ }^{14} \mathrm{C}\right]$ allantoin to measure the proportion of plasma $\left[{ }^{14} \mathrm{C}\right]$ allantoin excreted in urine does not require measurement of endogenous PD. The high level of precipitation of $\left[{ }^{14} \mathrm{C}\right]$ allantoin in the urine with mercuric acetate indicates that ${ }^{14} \mathrm{C}$ activity in the urine was mainly $\left[{ }^{14} \mathrm{C}\right]$ allantoin. Therefore, it can be used as an alternative method to measure the proportion of plasma PD excreted in urine.

The proportion of $\left[{ }^{14} \mathrm{C}\right]$ allantoin in plasma excreted in the urine in both Expts 1 and 2 showed that sheep eliminated plasma $\left[{ }^{14} \mathrm{C}\right]$ allantoin mainly via the kidneys. There was no effect of feed intake level on this proportion. Variations in GFR has been proposed as a factor affecting PD excretion, and it has been suggested by (Chen et al. 1995) that inclusion of estimation of GFR might improve the precision of models based on the estimation of plasma PD recovered in the urine. Labelled allantoin recovery was related to GFR in the sheep used in Expt 1. The high 
Table 5. Recovery $\left[{ }^{14} \mathrm{C}\right]$ allantoin and GFR in sheep from Expts 1 and 2

(Mean values and standard deviations for three experimental periods per sheep)

\begin{tabular}{crrrrr}
\hline & \multicolumn{2}{c}{ GFR (litres/d) } & & \multicolumn{2}{c}{ Recovery (\%) } \\
\cline { 2 - 3 } & Mean & SD & & Mean & SD \\
\hline Expt 1 & & & & \\
Sheep A & 139.0 & 24.4 & & 0.88 & 0.01 \\
Sheep B & 106.5 & 4.7 & & 0.80 & 0.06 \\
Sheep C & 99.5 & 8.5 & & 0.72 & 0.06 \\
Sheep D & 87.7 & 18.1 & & 0.73 & 0.03 \\
Expt 2 & & & & \\
Sheep E & 79.1 & 0.60 & & 0.84 & 0.04 \\
Sheep F & 82.5 & 7.7 & & 0.85 & 0.08 \\
Sheep G & 103.7 & 3.9 & 0.88 & 0.06 \\
Sheep H & 93.5 & 3.2 & 0.90 & 0.07 \\
\hline
\end{tabular}

positive relationship ( $r$ 0.76) between GFR/kg body weight ${ }^{0.75}$ and $\left[{ }^{14} \mathrm{C}\right]$ allantoin recovery in urine indicated that GFR influences recovery. However, this relationship was different in the sheep used in Expt 2, which showed significant differences of GFR but not in recovery of $\left[{ }^{14} \mathrm{C}\right]$ allantoin. A similar result for all sheep in Expts 1 and 2 was that variation in GFR in the same animal did not appear to affect recovery. There was no relationship between GFR and $\left[{ }^{14} \mathrm{C}\right]$ allantoin recovery in urine of eight sheep from both Expts 1 and 2 either shown as the individual values from three periods or shown as the average from three periods. Interestingly, the recovery of labelled allantoin in sheep A was not higher than sheep $\mathrm{G}$ or $\mathrm{H}$, although sheep A showed much higher GFR than sheep $\mathrm{G}$ or $\mathrm{H}$ (Table 5). The GFR of eight sheep (Expts 1 and 2) varied from 49 to 179 litres/d. GFR could be included as a correction factor in the model of PD excretion if it relates to the recovery of plasma PD in urine. However, because of variation between animals, this aspect of the present study was inconclusive. Knowledge of the extent to which GFR variation is related to plasma PD recovered in urine, obtained by studying a larger number of sheep, would be useful to refine existing mathematical models of PD excretion.

In previous studies, plasma PD recovered in the urine of sheep has been reported as total PD (Fujihara et al. 1987; Chen et al. 1990b, 1997), or as allantoin (Balcells et al. 1991; Chen et al. 1991; Surra et al. 1997; Kahn \& Nolan, 2000) mean values varied from 81 to $98 \%$ and 72 to $94 \%$ respectively. In Expts 1 and 2 the recovery of $\left[{ }^{14} \mathrm{C}\right]$ allantoin from eight sheep varied from 66 to $95 \%$ (mean value 83 (SE 1.6) \%) indicating a large variation between individuals. There was a tendency for sheep with high recoveries to have high recoveries in consecutive periods. With a recovery of $66 \%$ for one of sheep in Expt 1 , microbial protein supply would give rise to an error of approximately $20 \%$ using the model of Chen et al. $(1990 \mathrm{~b})$. With the maximum recovery of $95 \%$ in one observation from Expt 2, the overall range of recoveries was over $30 \%$. Thus, the estimation of rumen microbial protein supply could be considerably underestimated or overestimated according to between animal variation. In addition, Liang et al. (1999) and Prasitkusol (2001) showed there are differences of plasma PD recovered in urine between species of cattle. Pimpa et al. (2001) also showed different results between species. In order to improve the accuracy of estimation, existing models of purine excretion may need to be modified according to the proportion of plasma PD recovered in urine. Better knowledge of the variation in plasma PD recovery in urine between different breeds and species, and the effect of GFR on the renal clearance of PD excretion is needed to construct a more effective mathematical model for estimating rumen microbial protein supply from PD excretion in ruminant livestock.

\section{Acknowledgements}

The authors wish to thank International Atomic Energy Agency (IAEA) for the financial support under the joint project of International Feed Resources Unit (IFRU). We are grateful to Drs R.N.B. Kay and A.J. Travis for revision of the manuscript. Thanks also to Drs G. Horgan and G. Zurr of BIOSS for useful discussion on the statistical analysis.

\section{References}

Association of Official Analytical Chemists (1980) Official Methods of Analysis, 13th ed. Washington, DC: AOAC.

Ayala A \& Hovell FDDeB (1997) Nitrogen balance and rumen microbial nitrogen supply measured in Zebu bulls given young or mature Napier grass (Pennisetum purpureum). Proceedings of the Nutrition Society 56, 186A.

Balcells J, Guada JA, Castrillo C \& Gasa J (1991) Urinary excretion of allantoin and allantoin precursors by sheep after different rates of purine infusion into the duodenum. Journal of Agricultural Science, Cambridge 116, 309-317.

Chen XB, Fujihara T, Nakamura K, Mawuenyegah PO, Franklin MF \& Kyle DJ (1997) Response of urinary and plasma purine derivatives to various rates and infusion patterns of purines in sheep nourished by intragastric infusion. Journal of Agricultural Science, Cambridge 129, 343-352.

Chen XB, Hovell FDDeB \& Ørskov ER (1990a) Excretion of purine derivatives by ruminants: recycling of allantoin into the rumen via saliva and its fate in the gut. British Journal of Nutrition 63, 197-205.

Chen XB, Hovell FDDeB, Ørskov ER \& Brown DS (1990b) Excretion of purine derivatives by ruminants: effect of exogenous nucleic acid supply on purine derivative excretion by sheep. British Journal of Nutrition 63, 131-142.

Chen XB, Kyle DJ \& Ørskov ER (1993) Measurement of allantoin in urine and plasma by high-performance liquid chromatography with pre-column derivatization. Journal of Chromatography 617, 241-247.

Chen XB, Kyle DJ, Ørskov ER \& Hovell FDDeB (1991) Renal clearance of plasma allantoin in sheep. Experimental Physiology 76, 59-65.

Chen XB, Mathieson J \& Hovell FDDeB (1990c) Measurement of purine derivatives in urine of ruminants using automated methods. Journal of the Science of Food and Agriculture 53, $23-33$.

Chen XB, Susmel P, Stefanon B \& Ørskov ER (1995) On the use of purine derivatives in spot urine, plasma and milk samples as indicators of microbial protein supply in sheep and cattle. In Protein Metabolism and Nutrition. Proceedings of the 7th International Symposium on Protein Metabolism and Nutrition; 
Vale de Santarem - Portugal, vol. 81, pp. 325-329. Portugal: Estação Zootécnia, Instituto Nacional de Investigação Agrária.

Coleman GS (1968) The metabolism of bacterial nucleic acid and of free components of nucleic acid by the rumen ciliate Entodinium caudotum. Journal of General Microbiology 54, 83-96.

Emslie-Smith D, Paterson CR, Scratcherd T \& Read WN (1988) The Kidney. Textbook of Physiology, 11th ed. Edinburgh: Churchill Livingstone.

Fujihara T, Ørskov ER, Reeds PJ \& Kyle DJ (1987) The effect of protein infusion on urinary excretion of purine derivatives in ruminants nourished by intragastric nutrition. Journal of Agricultural Science, Cambridge 109, 7-12.

Hawk PB, Oser BL \& Summerson D (1965) Determination of creatinine. In Practical Physiological Chemistry, vol. 12, pp. 506-509: The Blakiston Co.

Kahn LP \& Nolan JV (2000) Kinetic of allantoin metabolism in sheep. British Journal of Nutrition 84, 629-634.

Kay RNB (1960) The rate of flow and composition of various salivary secretions in sheep and calves. Journal of Physiology 150, 515-537.

Liang JB, Pimpa O, Abdullah N \& Jelan ZA (1999) Estimation of rumen microbial protein production from urinary purine derivatives in Zebu cattle and water buffalo. In Nuclear Based Technologies for Estimating Microbial Protein Supply in Ruminant Livestock, IAEA-TECDOC-1093, pp. 35-42. Vienna: IAEA.

Menke KH \& Steingass H (1988) Estimation of the energenic feed value obtained from chemical analysis and in vitro gas production. Animal Research Development 28, 7-55.

Ørskov ER, Grubb DA, Wenham G \& Corrigall W (1979) The sustenance of growing and fattening ruminants by intragastric infusion of volatile fatty acid and protein. British Journal of Nutrition 41, 553-558.

Pimpa O, Liang JB, Jelan ZA \& Abdullah N (2001) Urinary excretion of duodenal purine derivatives in Kedah-Kelantan cattle. Animal Feed Science and Technology 92, 203-214.

Prasitkusol P (2001) Renal excretion and metabolism of uric acid and allantoin in sheep and cattle. PhD Thesis, University of Aberdeen.

Schäli C \& Roch-Ramel F (1980) Renal handling of $\left[{ }^{14}\right.$ C $]$ allantoin in the rabbit. Journal of Pharmacology and Experimental Therapeutics 213, 168-172.

Stefano AD, Pizzichini M, Leoncini R, Vagnoni DB, Pagani R \& Marinello E (1992) Quantitative separation of uric acid and allantoin from rat liver tissue. Biochimica et Biophysica Acta 1117, $1-6$.

Surra JC, Guada JA, Balcells J \& Castrillo C (1997) Renal and salivary clearance of purine derivatives in sheep. Journal of Animal Science 65, 83-91.

Terzuoli L, Pandolfi ML, Arezzini L, Pizzichini M, Marinello E \& Pagani R (1995) Separation and determination of liver uric acid and allantoin. Journal of Chromatography $B \mathbf{6 6 3}$, $143-147$

Vogels GD \& Van Drift C (1976) Degradation of purines and pyrimidines by microorganisms. Bacteriological Reviews 40, 403-468.

Verbic J, Chen XB, MacLeod NA \& Ørskov ER (1990) Excretion of purine derivatives by ruminants. Effect of microbial nucleic acid infusion on purine derivative excretion by steers. Journal of Agricultural Science, Cambridge 114, 243-248. 